\title{
KONSEP DAN PERSEPSI MASYARAKAT ETNIS MEYAH TENTANG HUTAN ADAT DI KAMPUNG MEREJEMEG KABUPATEN MANOKWARI
}

\author{
Concept and Perception Of meyah Ethnic Communities on Indigenous Forsets in \\ Merejemeg Village Manokwari Regency
}
Yohanes Yoseph Rahawarin ${ }^{1 *}$, Adolof Wam $^{2}$, Kristian Imburi ${ }^{1}$, Reinardus Liborius Cabuy ${ }^{1}$, Alexander Rumatora ${ }^{1}$

${ }^{1}$ Program Studi Kehutanan Fakultas Kehutanan Universitas Papua, Manokwari Balai Konservasi Sumberdaya Alam Manokwari

`Email : jo.rahawarin@gmail.com

Diterima: 03/06/2021, Direvisi: 27/07/2021, Disetujui: 29/07/2021

\begin{abstract}
The study was aimed to obtain the concept of indigenous forest according to the Meyah ethnic community, the Meyah ethnic community's perception of indigenous forest, and the factors that influence the use of the indigenous forest by the Meyah ethnic community. Descriptive methods with observation and interview techniques are used in this study. Respondents were selected by purposive sampling, as many as 30 families. The results show that the concept of indigenous forest according to the Meyah ethnic community is a forest area given by God the Creator of the Universe as human property rights to live for generations, reproduce and adapt to their environment, and utilize the resources in the forest. Ownership of indigenous forests is controlled by individuals or clan groups for generations in certain areas marked by natural boundaries. The first activity in utilizing the forest as a source of life was by clearing land for houses and gardening as well as collecting forest products, which were used as the basis for determining the boundaries of land and forest rights. The Meyah ethnic community has a strong perception of indigenous forests, both perceptions of indigenous forest ownership, indigenous forest sustainability, and indigenous forest use. The factors that influence the Meyah ethnic community in the use of indigenous forests consist of a) determining factors, namely: customs and way of life about the forest; b) supporting factors, namely: livelihood and length of stay, and c) driving factors, namely: the role of traditional and religious leaders.
\end{abstract}

Keywords: Concept, Perception, Indigenous Forest, Meyah Ethnic, Manokwari

\begin{abstract}
ABSTRAK
Tujuan penelitian ini adalah mengetahui konsep hutan adat menurut masyarakat etnis Meyah, persepsi masyarakat etnis Meyah tentang hutan adat serta faktor-faktor yang mempengaruhi pemanfaatan hutan adat oleh masyarakat etnis Meyah. Metode deskriptif dengan teknik observasi dan wawancara digunakan dalam penelitian ini. Responden dipilih secara pusposive sampling, sebanyak 30 kepala keluarga. Hasil penelitian menunjukkan bahwa konsep hutan adat menurut masyarakat etnis Meyah adalah areal hutan yang diberikan oleh Tuhan Pencipta Alam Semesta sebagai hak milik manusia untuk hidup secara turuntemurun, berkembang biak dan beradaptasi dengan lingkungannya, serta memanfaatkan sumberdaya yang ada di dalam hutan. Kepemilikan hutan adat dikuasai oleh individu atau
\end{abstract}


kelompok marga secara turun temurun dalam luasan tertentu yang ditandai oleh batas-batas alam. Aktifitas pertama kali dalam memanfaatkan hutan sebagai sumber kehidupan adalah dengan membuka lahan untuk rumah dan berkebun serta memungut hasil hutan, dijadikan dasar penentuan batas-batas hak atas tanah dan hutan. Masyarakat etnis Meyah memiliki persepsi yang kuat tentang terhadap hutan adat, baik persepsi tentang kepemilikan hutan adat, kelestarian hutan adat maupun pemanfaatan hutan adat. Faktor-faktor yang mempengaruhi masyarakat etnis Meyah dalam pemafaatan hutan adat terdiri atas a) faktor penentu yaitu: adat istiadat dan pandangan hidup tentang hutan; b) faktor pendukung yaitu: matapencaharian dan lama bermukim, serta c) faktor pendorong yaitu: peran dari tokoh adat dan tokoh agama.

Kata kunci: Konsep, Persepsi, Hutan Adat, Etnis Meyah, Manokwari

\section{PENDAHULUAN}

Hutan memegang peran unik baik sebagai sistem penyangga kehidupan maupun sebagai penggerak ekonomi di banyak negera. Hutan tropika dikenal memiliki biodiversitas yang tinggi serta merupakan tempat tersimpannya sumberdaya genetik flora dan fauna yang penting untuk pemenuhan kebutuhan akan produk kayu dan non kayu, pertanian, obat-obatan dan lain-lain (Masripatin. 2007). Peran hutan yang demikian, membuat masyarakat memanfaatkan hutan dengan segala keanekaragamannya. Aktivitas perambahan dan illegal loging yang terjadi di hutan telah menyebabkan perubahan keanekaragaman hayati di dalamnya yang sampai sekarang banyak diantaranya belum diketahui manfaatnya. Kondisi ini mengurangi kapasitas hutan untuk memberikan jasa sebagaimana fungsinya.

Salah satu masalah dalam pengelolaan hutan adalah kondisi sosial ekonomi masyarakat sekitar hutan yang tergolong rendah. Masyarakat lokal sekitar hutan umumnya bergantung pada hutan sebagai sumber mata pencaharian, namun kehidupannya masih jauh dari standar sejahtera dengan fasilitas umum yang kurang memadai (Magdalena 2013). Keberadaan masyarakat lokal dengan kearifan lokal yang dimiliki mampu menjaga kawasan hutan, bukan malah terpinggirkan dan tidak terlindungi hak dasarnya, bahkan kadang dianggap sebagai sumber konflik. Melalui pengelolaan hutan berbasis masyarakat diharapkan tingkat pendapat dan ekonomi masyarakat semakin meningkat, sehingga tidak lagi terjadi kegiatan penebangan liar ataupun perambahan hutan (Farouque et al. 2017; Andrasmoro dan Nurekawati 2017; Negara 2011; Ruhimat 2010). Hal ini seperti ditemukan Syahputra et al. (2021) dalam pengelolaan kolaboratif berbasis masyarakat pada hutan mangrove di Provinsi Aceh. Masyarakat lokal/tradisional sekitar hutan memiliki tanggung jawab cukup besar dalam pengelolaan hutan di sekitar pemukimannya. Pengelolaan hutan yang baik akan memberikan kontribusi positif terhadap pelestarian keanekaragaman hayati. Semakin luas masyarakat diberi kesempatan untuk berpartisipasi dalam mengelola hutannya, semakin tinggi pula rasa memilki hutan tersebut.

Terdapat pengakuan yang berkembang bahwa keberhasilan pengelolaan kawasan hutan pada akhirnya bergantung pada kerja sama dan dukungan masyarakat lokal, sehingga strategi perlindungan hutan dengan mengasingkan masyarakat lokal dari kawasan hutan, bukan hanya tidak adil dan tidak menghormati hak fundamentalnya, tetapi juga akan merugikan upaya-upaya pelestarian hutan itu sendiri. Apalagi menyangkut hutan sebagai sumber daya milik bersama, masyarakat adalah aktor penting dalam pengelolaan sumber daya alam (Wells dan Brandon 1993; Kothari et al. 1995; dan Agrawal 2003). Menurut Siu et al. (2020), bahwa salah satu aspek yang sangat menentukan keberlanjutan pengelolaan kawasan hutan adalah masyarakat lokal, karena bukan hanya bergantung pada potensi sumberdaya hutan tetapi juga lebih merasakan dampak yang timbul pada kawasan hutan. 
Kelestarian kawasan hutan dan kehidupan masyarakat tradisional yang hidup di dalam dan sekitarnya saling mempengaruhi. Kelestarian hutan sangat dipengaruhi oleh kehidupan masyarakat tradisional, sebaliknya kelompok masyarakat sangat bergantung pada kawasan hutan tersebut. Keterlibatan aktif masyarakat untuk mengelola hutan dapat dilakukan dalam melindungi hutan sesuai dengan aspirasi masyarakat setempat (Sahlan 2012 dan Muspidan 2008). Hasil penelitian Susanto et al. (2020) di kawasan Cagar Alam Pangandaran mengatakan bahwa aktivitas masyarakat dengan kawasan hutan tidak dapat dihindari, karena kawasan ini merupakan sumber pendapatan bagi masyarakat yang sudah lama berinteraksi sebelum ditetapkan sebagai cagar alam.

Pemerintah telah berupaya agar keterlibatan masyarakat dalam pengelolaan hutan menjadi salah satu upaya dalam memberikan akses kepada masyarakat. Bukan saja melalui perhutanan sosial, pengelolaan hutan lindung dengan partisipasi masyarakat, tetapi pemerintah juga memberikan pengakuan terhadap hutan adat. Laporan LHK (2018) tentang status hutan dan kehutanan menjelaskan bahwa hutan adat harus dikelola sesuai dengan fungsi hutan yang ditentukan. Menurut KEMENDAGRI (2014) dalam Permendagri Nomor 52 Tahun 2014 dijelaskan bahwa, wilayah adat adalah tanah adat yang berupa tanah, air, dan atau perairan beserta sumber daya alam yang ada di atasnya dengan batas-batas tertentu, dimiliki, dimanfaatkan dan dilestarikan secara turun-temurun dan secara berkelanjutan untuk memenuhi kebutuhan hidup masyarakat yang diperoleh melalui pewarisan dari leluhur mereka atau gugatan kepemilikan berupa tanah ulayat atau hutan adat. Putri et al. (2019), menjelaskan bahwa kawasan hutan adat kedudukannya khusus (lex specialis), dimana hak menguasai oleh negara tidak berlaku, namun dimungkinkan hubungan fungsionalnya dapat diatur.

Salah satu areal hutan adat yang berada di Provinsi Papua Barat adalah wilayah masyarakat adat etnis Meyah di Kampung Merejemeg Distrik Masni Kabupaten Manokwari. Etnis Meyah merupakan salah etnis asli dalam suku besar Arfak yang mendiami sebelah Barat Pegunungan Arfak, termasuk wilayah dataran Prafi di Kabupaten Manokwari. Areal hutan yang terdapat di sekitar kampung Merejemg termasuk dalam kawasan hutan lindung. Masyarakat adat setempat menganggap bahwa hutan berada di sekitar kampungnya merupakan hutan adat yang sudah dimiliki secara turun temurun sejak jaman nenek moyang. Hutan memberikan manfaat ekonomi, sosial dan budaya untuk meningkatkan ekonomi keluarga. Persepsi masyarakat tentang kawasan hutan dipengaruhi oleh manfaat yang dirasakan dari kawasan hutan (Chowdhury et al. 2014; dan Ratsimbazafy et al. 2012). Masyarakat lokal diperkirakan akan memiliki persepsi positif terhadap pengelolaan dan pelestarian hutan jika mendapat manfaat yang diperoleh dari hutan. (Badola et al. 2012; Infield dan Namara 2001; Takon et al. 2013). Atas dasar pemikiran yang diuraikan di atas maka penelitian ini bertujuan untuk: 1) Mengetahui konsep hutan adat menurut masyarakat etnis Meyah; 2) Persepsi masyarakat etnis Meyah tentang hutan adat; 3) Faktor-faktor penentu yang mempengaruhi masyarakat etnis Meyah memanfaatkan hutan adat.

\section{METODE}

\section{A. Waktu dan Lokasi Penelitian}

Waktu penelitian dari bulan Januari sampai dengan bulan Februari 2020. Penelitian ini dilaksanakan di Kampung Merejemeg, Distrik Masni, Kabupaten Manokwari. Kampung ini terletak di pinggir jalan arteri trans provinsi yang menuju ke beberapa kabupaten lainnya seperti Sorong, Tambrauw dan Pegunungan Arfak. Beberapa wilayah distrik yang berbatasan dengan 
Kampung Merejemeg di Distrik Masni seperti Distrik Sidey, Prafi dan Warmare merupakan areal pekerbunan kelapa sawit.

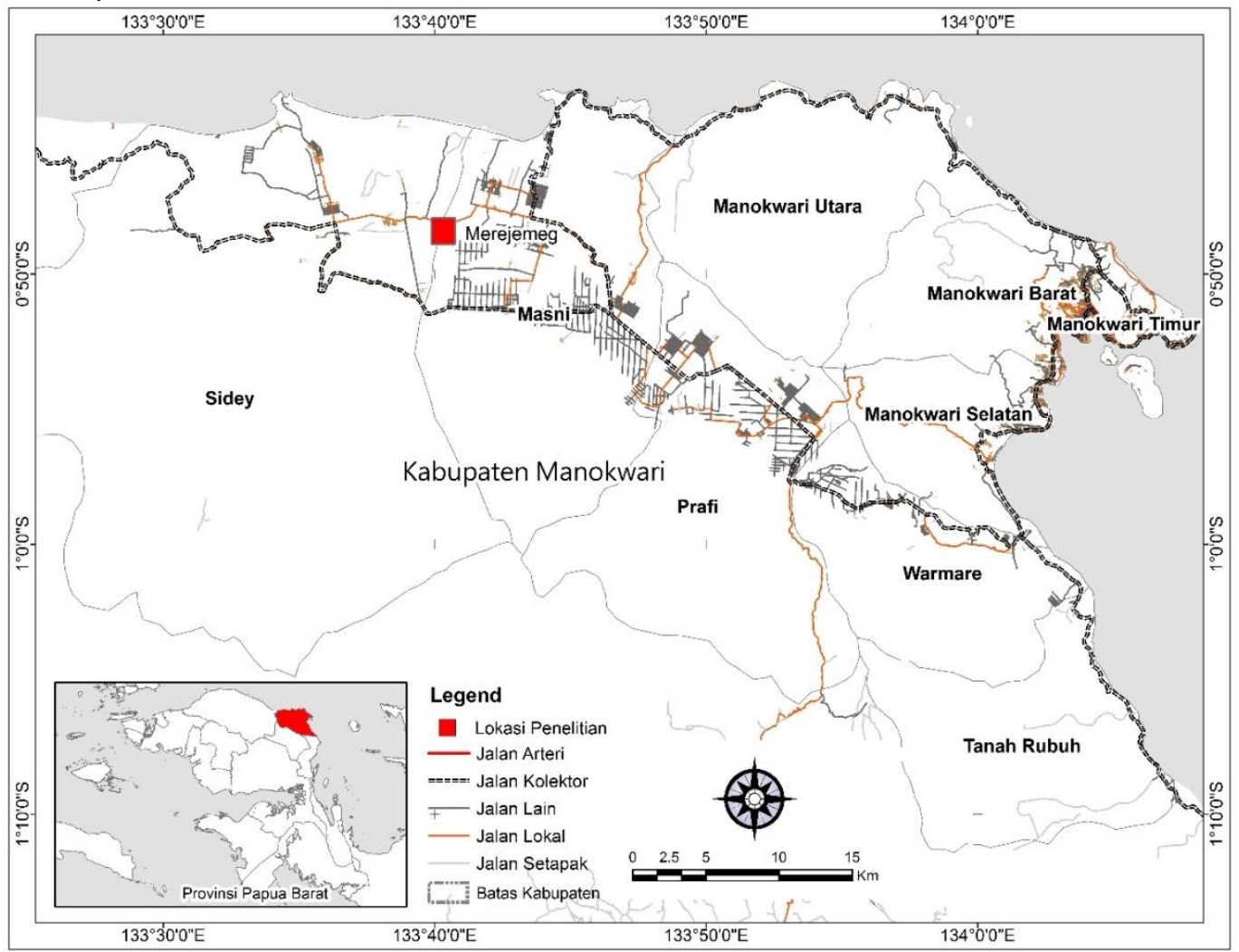

Gambar 1. Peta Lokasi Penelitian

Figure 1. Research Location Map

\section{B. Teknik Pengumpulan Data}

Penelitian dirancang dalam metode deskriptif. Data dikumpulkan dengan teknik observasi dan wawancara. Guna memperoleh deskripsi yang lengkap mengenai fenomena dari populasi, maka penelitian ini disusun secara sistematis berdasarkan fakta dan sifat dari populasi itu sendiri. Responden dipilih secara pusposive sampling berdasarkan tingkat pengetahuan masyarakat terhadap hutan adat. Berdasarkan rumus Slovin (Sugiyono 2011), maka jumlah responden sebanyak $30 \mathrm{KK}$ (kepala keluarga) dari jumlah KK ada di kampung Merejemeg. Responden dikelompokkan dalam 3 kelompok, dimana masing-masing kelompok memiliki tingkat pengetahuan atau pemahaman yang berbeda mengenai hutan adat. Kelompok pertama berjumlah 10 (sepuluh) KK, terdiri dari tokoh masyarakat atau tokoh adat (kepala suku/marga) yang lebih mengetahui tentang areal hutan. Kelompok kedua adalah aparat pemerintah kampung/distrik berjumlah 5 (lima) KK yang bertugas mengurus aktivitas sosial, ekonomi dan budaya masyarakat. Kelompok ketiga berjumlah 15 (lima belas) KK yang terdiri dari masyarakat adat etnis Meyah yang beraktivitas memanfaatkan areal hutan adat.

Alat dan bahan sebagai instrumen penelitian meliputi panduan dokumentasi, panduan wawancara, serta media atau perangkat penunjang. Kuisioner memuat pertanyaan yang menghasilkan jawaban responden mengenai: (a) identitas atau profil responden; (b) Konsep dan pandangan masyarakat etnis Meyah tentang hutan, (b) Persepsi masyarakat etnis Meyah 
terhadap hutan adat, dan (c) Faktor-faktor penentu yang mempengaruhi masyarakat etnis Meyah dalam pemanfaatan hutan adat. Data dan informasi lain yang dikumpulkan adalah gambaran umum lokasi penelitian serta penelusuran pustaka.

\section{Analisa Data}

Pengolahan dan analisis data dilakukan atas pertanyaan yang diajukan mengenai konsep hutan adat menurut masyarakat, persepsi masyarakat tentang hutan adat, serta faktor-faktor penentu yang mempengaruhi masyarakat memanfaatkan hutan adat. Persepsi masyarakat etnis Meyah tentang hutan adat dianalisis dengan skala Likert (Riduwan 2008) yang terdiri atas: a) Persepsi masyarakat tentang kepemilikan hutan adat, b) Persepsi masyarakat tentang kelestarian hutan adat, dan c) Persepsi masyarakat tentang pemanfaatan hutan adat. Setiap jawaban/pernyataan responden diberi skor penilaian dengan skala persepsi; Kuat atau positif (Nilai=5), Cukup netral (Nilai=3), dan Lemah atau negatif (Nilai=1). Skor penilaian responden tentang persepsi (Tabel 1), sedangkan skor bobot kelompok responden (Tabel 2), dan klasifikasi dan kategori persepsi (Tabel 3). Rumus untuk menghitung Skor Akhir Persepsi (SAP) adalah:

$$
\begin{aligned}
\mathrm{SAP}= & \sum(\mathrm{Ni} \times \mathrm{SP} \times \mathrm{BR}) \text {, dimana; } \\
& \mathrm{Ni}=\text { Jumlah responden yang menjawab sesuai skor penilain } \\
& \mathrm{SP}=\text { Skor Penilaian } \\
& \mathrm{BR}=\text { Bobot Responden }
\end{aligned}
$$

Tabel 1. Skor Penilaian Persepsi

Table 1. Perception Assessment Score

\begin{tabular}{clc}
\hline No & \multicolumn{1}{c}{ Persepsi } & Skor Penilaian \\
\hline 1 & Kuat atau positif & 5 \\
\hline 2 & Cukup atau netral & 3 \\
\hline 3 & Lemah atau negatif & 1 \\
\hline
\end{tabular}

Tabel 2. Skor Bobot Responden

Table 2. Respondents' Weight Score

\begin{tabular}{cccc}
\hline No & Kelompok Responden & Bobot Responden & Jumlah Resonden \\
\hline 1 & Tokoh Masyarakat & 3 & 15 \\
\hline 2 & Aparat Pemerintah & 2 & 5 \\
\hline 3 & Masyarakat Adat & 1 & 10 \\
\hline & Jumlah & & $\mathbf{3 0}$
\end{tabular}

Sumber: Modifikasi dari skala likert (Riduwan, 2008)

Tabel 3. Klasifikasi dan Kategori Persepsi

Table 3. Classification and Categories of Perception

\begin{tabular}{cccc}
\hline No & $\begin{array}{c}\text { Interval } \\
\text { Skor Persepsi }\end{array}$ & \multicolumn{1}{c}{ Klasifikasi } & \multicolumn{1}{c}{ Kategori Persepsi } \\
\hline 1 & $55-128$ & Lemah/Negatif & Tidak Memahami/Tidak Mengetahui \\
\hline 2 & $129-202$ & Cukup/Netral & Kurang Memahami/Kurang Mengetahui \\
\hline 3 & $203-276$ & Kuat/Positif & Memahami/Mengetahui \\
\hline
\end{tabular}

Sumber: Modifikasi dari skala likert (Riduwan, 2008)

Analisis Faktor-faktor penentu yang mempengaruhi masyarakat etnis Meyah memanfaatkan hutan adat adalah: (a) Faktor dasar, (b) Faktor pendukung, dan (c) Faktor pendorong (Situmorang dan Simanjuntak 2015). Faktor determinan ini dianalisis secara 
deskriptif berdasarkan jawaban responden atas pertanyaan yang diberikan. Hasil pengolahan dan analisis data ditampilkan dalam bentuk tabel dan narasi.

\section{HASIL DAN PEMBAHASAN}

\section{A. Aspek Sosial Ekonomi dan Budaya Masyarakat}

Aspek sosial ekonomi dan budaya masyarakat yang dikaji meliputi umur, pendidikan, pekerjaan, pendapatan, suku serta lama bermukim. Masyarakat kampung Merejemeg yang dijadikan sebagai responden sebanyak 30 orang yang terdiri atas 22 orang pria $(73,33 \%)$ dan 8 orang wanita $(26,67 \%)$. Karakteristik sosial ekonomi dan budaya masyarakat seperti pada Tabel 4.

Tabel 4. Karakteristik Sosial Ekonomi dan Budaya Masyarakat Table 4. Socio-Economic and Cultural Characteristics of the Community

\begin{tabular}{|c|c|c|c|c|}
\hline No & Karakateristik & Kategori & Jumlah & Persentase (\%) \\
\hline \multirow[t]{3}{*}{1} & Suku & Papua Asli & 22 & 73.33 \\
\hline & & Papua Lain & 3 & 10.00 \\
\hline & & Non Papua & 5 & 16.67 \\
\hline \multirow[t]{5}{*}{2} & Lama bermukim & $<5$ tahun & 2 & 6.67 \\
\hline & & 6 - 10 tahun & 3 & 10.00 \\
\hline & & $11-15$ tahun & 3 & 10.00 \\
\hline & & $16-20$ tahun & 7 & 23.33 \\
\hline & & $>20$ tahun & 15 & 50.00 \\
\hline \multirow[t]{5}{*}{3} & Umur & $24-32$ tahun & 5 & 16.67 \\
\hline & & $33-41$ tahun & 9 & 30.00 \\
\hline & & $42-50$ tahun & 8 & 26.67 \\
\hline & & 51 - 59 tahun & 7 & 23.33 \\
\hline & & $>59$ tahun & 1 & 3.33 \\
\hline \multirow[t]{6}{*}{4} & Pendidikan & Tidak Sekolah & 15 & 50.00 \\
\hline & & SD & 6 & 20.00 \\
\hline & & SMP & 2 & 6.67 \\
\hline & & SMA/SMK & 3 & 10.00 \\
\hline & & DIPLOMA & 2 & 6.67 \\
\hline & & SARJANA & 2 & 6.67 \\
\hline \multirow[t]{3}{*}{5} & Pekerjaan & Petani & 22 & 73.33 \\
\hline & & Wiraswasta & 6 & 20.00 \\
\hline & & PNS & 2 & 6.67 \\
\hline \multirow[t]{4}{*}{6} & Pendapatan & $500.000-1.000 .000$ & 22 & 73.33 \\
\hline & & $1.000 .000-1.500 .000$ & 4 & 13.33 \\
\hline & & $1.500 .000-2.000 .000$ & 2 & 6.67 \\
\hline & & $>2.000 .000$ & 2 & 6.67 \\
\hline
\end{tabular}


Karakteristik masyarakat di kampung Merejemg berdasar profil responden menunjukkan bahwa sebagian besar (73,33\%) penduduk adalah masyarakat etnis Meyah yang merupakan penduduk asli (Tabel 4), sisanya adalah penduduk Papua lain (etnis Biak, Serui dan Sorong) serta penduduk Non Papua (etnis Jawa, Timur dan Buton). Masyarakat etnis Meyah merupakan warga masyarakat yang paling lama tinggal dan bermukim wilayah ini (di atas 20 tahun), sedangkan etnis lain baru bermukim $2-3$ tahun terkahir. Usia masyarakat yang terbanyak berkisar antara 33 - 41 tahun (30,00\%), diikuti dengan kisaran umur 42 - 50 tahun $(26,67 \%)$ dan usia 51 - 59 tahun (23,33\%), dan usia $24-32$ tahun (16,67\%). Persentase responden paling banyak berada pada usia produktif ( $24-59$ tahun), sedangkan yang usia di atas 59 tahun tidak produktif (3,33\%). Menurut Erwiantono (2006) bahwa, usia masyarakat yang lebih muda memilki produktivitas yang tinggi, sehingga lebih mudah menerima inovasi untuk kemajuan dalam mengelola ekosistem hutan.

Berdasarkan tingkat pendidikan, sebesar 50\% masyarakat tidak bersekolah, $20 \%$ yang berpendidikan SD, 10\% yang berpendidikan SMA/SMK. Sedangkan sisanya $6,67 \%$ hanya berpendidikan masing-masing SMP, Diploma dan Sarjana. Masyarakat dengan tingkat pendidikan yang rendah cenderung memiliki cara berpikir dan bertindak yang lambat dalam proses pengambilan keputusan, termasuk keputusan mengenai pengelolaan sumber daya hutan. Rusdianti dan Sunito (2012) mengatakan bahwa tingkat pendidikan juga mempengaruhi bagaimana individu ikut serta dalam suatu kegiatan. Sedangkan menurut Rahlem et al. (2017), perbedaan tingkat pendidikan setiap orang berpengaruh terhadap pola pikir dan partisipasi baik dalam mengelola maupun menjaga keberadaan wisata alam ini.

Jika ditinjau dari segi pekerjaan atau matapencaharian, maka masyarakat kampung Merejemeg sebagian besar (73,33\%) adalah petani. Bekerja sebagai wiraswasta hanya $20,00 \%$ dan sedikit yang bekerja sebagai PNS (6,67\%). Hal tersebut menunjukan bahwa aktivitas memanfaatkan lahan hutan sebagai tempat bekerja adalah merupakan sumber utama kehidupan.

Kristin et al. (2018) menjelaskan bahwa interaksi masyarakat terhadap hutan dalam memenuhi kebutuhan, semakin meningkat dipengaruhi oleh tingkat pendapatan. Sebagian besar $(73,33 \%)$ masyarakat berpenghasilan di bawah Rp 1.500.000. Kondisi sosial ekonomi masyarakat dari aspek pendapatan tergolong kelompok masyarakat miskin (Ritohardoyo dan Ardi 2011).

\section{B. Konsep Hutan Adat Menurut Masyarakat Etnis Meyakh}

Berdasarkan hasil wawancara diketahui bahwa sejak dulu masyarakat etnis Meyah telah memiliki pemahaman tentang konsep hutan di sekitar tempat tinggalnya, yang selanjutnya dikenal sebagai hutan adat. Menurut tradisi dan adat istiadat masyarakat etnis Meyah, bahwa hutan adat adalah areal hutan yang diberikan oleh Tuhan Pencipta Alam Semesta sebagai hak milik manusia secara turun-temurun untuk hidup/berkembang biak dan beradaptasi dengan lingkungannya. Masyarakat etnis Meyakh mengetahui bahwa kepemilikan hutan adat dikuasai oleh individu atau kelompok marga secara turun temurun dalam luasan tertentu yang ditandai oleh batas-batas alam. Aktifitas pertama kali dalam memanfaatkan sumber daya hutan sebagai sumber kehidupan dengan membuka lahan untuk rumah dan berkebun serta memungut hasil hutan, dijadikan sebagai dasar penentuan batas-batas hak atas lahan dan hutan.

Menurut pandangan masyarakat etnis Meyah di Kampung Merejemeg hak atas lahan dan hutan adat yang diwariskan, meliputi: hak atas sumber daya alam di atas tanah (air, batu, pasir, flora dan fauna) serta yang terkandung di dalam tanah (bahan tambang emas, minyak bumi, batu bara dan lainnya) telah menjadi hak miliknya yang ditentukan dan disepakati sejak jaman nenek moyang. Batas hak wilayah atas tanah dan hutan adat ditentukan berdasarkan aktifitas atau pergerakan individu, kelompok marga, atau keluarga dalam memanfaatkan sumberdaya alam. Seberapa luas atau sempitnya batas hak hutan adat, disepakati dan 
ditentukan berdasarkan sejauh mana pergerakan dalam memanfaatkan lahan hutan untuk kebun yang ditandai dengan areal bekas kebun, atau areal bekas memungut dan mengolah hasil hutan. Ciri-ciri batas dari masing-masing areal hak hutan adat biasanya disepakati berdasarkan batas gunung, batas kali, batas pohon besar, batas batu besar, batas danau dan simbol alam lainnya. Lokasi atau tempat dimana masyarakat etnis Meyah pertama kali berjalan mengelilingi alam, memanfaatkan sumberdaya alam seperti disajika pada Tabel 5.

Tabel 5. Lokasi aktivitas masyarakat etnis Meyah sebagai batas hak adat

Table 5. Locations of activities of the Meyah ethnic community as boundaries of customary rights

\begin{tabular}{cll}
\hline No & \multicolumn{1}{c}{ Lokasi Aktivitas Sebagai Batas Hak Adat } & \multicolumn{1}{c}{$\begin{array}{c}\text { Nama Lokal } \\
\text { (Bahasa Meyah) }\end{array}$} \\
\hline 1 & Tempat menangkap belut & ruhur mei \\
\hline 2 & Tempat berkebun & merefta \\
\hline 3 & Tempat bekas kebun & mofa \\
\hline 4 & Tempat bekas rumah & moduiws \\
\hline 5 & Tempat mencari ikan & ribesengka mei \\
\hline 6 & Tempat berburu kus-kus pohon & raga mesta ofou \\
\hline 7 & Tempat berburu rusa dan babi & rima \\
\hline 8 & Tempat mengambil kulit kayu untuk dinding rumah & ruj monska \\
\hline 9 & Tempat mengambil batang pohon untuk rumah & ris megaofor \\
\hline 10 & Tempat mengambil tali rotan untuk rumah & rira mofun \\
\hline 11 & Tempat mengambil atap daun untuk rumah & rab mejefeyi \\
\hline
\end{tabular}

Berdasarkan hasil wawancara dengan tokoh masyarakat (tokoh adat dan tokoh agama) etnis Meyah, diketahui bahwa hutan yang telah dibebani hak adat atas batas-batas alam ini telah lama ada dan diwariskan dari generasi ke generasi. Kehadiran status dan fungsi hutan yang ditetapkan pemerintah membuat masyaraka adat menjadi serba salah atau dilema, karena sejauh ini belum ada pengakuan pemerintah terhadap hutan adat yang lebih dulu dikuasai oleh masyarakat adat secara turun temurun.

Sistem penguasaan lahan hutan oleh masyarakat etnis Meyah terbagi terbagi atas 3 bentuk yaitu: 1) penguasaan lahan hutan sebagai satu kesatuan wilayah adat dengan kampung, 2) penguasaan lahan hutan oleh kelompok marga dan 3) penguasaan lahan hutan oleh individu (keluarga). Ketiga sistem penguasaan lahan hutan tersebut diatur berdasarkan aturan dan norma yang berlaku dalam masyarakat adat. Namun menurut Febryano et al. (2015) dan Budiandrian et al. (2017) bahwa faktor kebijakan dan hukum yang berlaku untuk pemanfaatan kawasan hutan berpengaruh terhadap legitimasi atas lahan hutan.

Lahan berupa tanah dan hutan bagi masyarakat adat etnis Meyah merupakan batasan penguasaan secara keseluruhan wilayah yang dimiliki oleh masyarakat sebagai warisan leluhur untuk dimanfaatkan oleh seluruh masyarakat asli yang menempati wilayah tersebut. Semua anggota masyarakat asli etnis Meyah berhak memungut hasil hutan dalam wilayah kampung, sedangkan masyarakat luar (bukan masyarakat asli) boleh memungut hasil hutan atau menggarap lahan apabila telah mendapat ijin dari lembaga masyarakat adat atau kepala suku.

Lahan hutan marga merupakan lahan milik bersama oleh keluarga-keluarga yang tergabung dalam satu kelompok marga. Pengaturan pengelolaan lahan marga dilakukan oleh kepala marga yang ditunjuk oleh anggota marga. Seluruh anggota marga berhak untuk memanfaatkan hasil hutan dalam lahan tersebut. Komposisi jenis tumbuhan pada lahan marga umumnya berupa hutan alam termasuk buah-buahan dan satwa yang menempati lahan tersebut. Pemanfaatan hasil hutan pada lahan marga lebih bersifat subsisten untuk kebutuhan anggota marga, tidak untuk dijual.

Lahan hutan individu atau keluarga merupakan bagian dari lahan marga yang diberikan kepada anggota marga (keluarga) untuk sepenuhnya menjadi milik keluarga tersebut. Penguatan kepemilikan lahan keluarga biasanya diusahakan dengan menanam tanaman 
campuran misalnya ubi jalar (Ipomoea batatas), ubi kayu (Manihot utilisima), tebu (Saccarum offisinnarum) dan pisang (Musang paradiaca), mangga (Mangifera indica), jeruk nipis (Citrus sinensis), kelapa (Cocos nucifera), nangka (Artocarpus heterophyllus), durian (Durio zibethinus), rambutan (Nephelium lappaceum), pinang (Areca catechu), kakao (Theobroma cacao). Keputusan mengenai pengelolaan dan pemanfaatan lahan hutan ini menjadi tanggungjawab dari kepala keluarga beserta anggota keluarganya.

Selain sistem penguasaan lahan hutan terdapat pula hak-hak yang melekat pada setiap sistem tersebut. Penguasaan tanah dan hutan adat oleh masyarakat etnis Meyah dipahami sebagai bentuk kepemilikan atas lahan hutan berdasarkan aturan adat yang disepakati. Salah satu strategi melestarikan hutan adalah mengakomodir hak masyarakat adat. Fajrini (2015)

menjelaskan bahwa Konvensi Keanekaragaman Hayati (UN Convention on Biodiversity/UNCBD) merupakan instrumen hukum internasional yang mengakui kearifan lokal masyarakat adat dengan konservasi keanekaragaman hayati. Konvensi ini melindungi kearifan lokal masyarakat adat dengan menjamin integritas budaya, mendorong penggunaan sumber daya hayati tradisional yang berkelanjutan dan menghargai struktur pembuatan kebijakan dalam masyarakat adat.

\section{Persepsi Masyarakat Mengenai Hutan Adat}

Persepsi adalah proses perekaman makna oleh panca indra atau pemahaman makna atas suatu obyek atau informasi. Pengetahuan masyarakat yang baik akan menduku persepsi masyarakat yang positif (Putri et al. 2019). Hasil penelitian Dewi et al. (2019) menunjukkan bahwa persepsi masyarakat yang positif akan mendukung terhadap manajemen pengelolaan. Perilaku dari masyarakat dapat dipengaruhi oleh persepsi masyarakat, yaitu pengetahuan dan pengalaman tentang sumber daya hutan (Tadese dan Taketay 2017).

\section{Persepsi Masyarakat tentang Kepemilikan Hutan Adat}

Berdasarkan aspek kepemilikan terhadap hutan adat, hasil wawancara menunjukkan bahwa masyarakat etnis Meyah mempunyai persepsi yang kuat terhadap kepemilikan hutan adat adalah kuat (skor 265). Hal ini berarti masyarakat memahami bahwa hutan yang berada di sekitar kampung merupakan hutan adat yang menjadi miliknya. Dukungan demikian membuat masyarakat adat berharap adanya pengakuan terhadap hutan adat, sehingga dengan adanya program pembangunan kehutanan lebih tertuju ke masyarakat pemilik hutan adat. Dengan demikian dapat membantu masyarakat adat dalam meningkatkan ekonomi keluarga. Persepsi responden terhadap kepemilikan hutan adat di Kampung Merejemeg disajikan pada Tabel 6.

Tabel 6. Persepsi Masyarakat tentang Kepemilikan Hutan Adat

Table 6. Community Perceptions of Customary Forest Ownership

\begin{tabular}{|c|c|c|c|c|c|c|c|}
\hline \multirow{2}{*}{$\begin{array}{c}\text { Jenis } \\
\text { Responden }\end{array}$} & \multirow{2}{*}{ BR } & \multirow{2}{*}{$\begin{array}{l}\text { Persespsi } \\
\text { Responden }\end{array}$} & \multirow{2}{*}{ SP } & \multicolumn{3}{|c|}{ Jumlah } & \multirow{2}{*}{ SAF } \\
\hline & & & & TM & AP & MA & \\
\hline TM & 3 & Kuat & 3 & 10 & 3 & 14 & 250 \\
\hline AP & 2 & Netral & 2 & 0 & 2 & 1 & 15 \\
\hline \multirow[t]{2}{*}{ MA } & 1 & Lemah & 1 & 0 & 0 & 0 & 0 \\
\hline & & JUMLAH & & 10 & 5 & 15 & 265 \\
\hline
\end{tabular}

Keterangan: $\mathrm{TM}=$ Tokoh Masyarakat; $\mathrm{AP}=$ Aparat Pemerintah; $\mathrm{MA}=$ Masayarakat Adat/Kampung

$\mathrm{BR}=$ Bobot Responden; SP $=$ Skor Penilain; SAP $=$ Skor Akhir Persepsi Klasifikasi Persepsi: 55 - 128 (Lemah); 129 - 202 (Netral); 203 - 276

(Kuat) 
Masyarakat adat etnis Meyah telah lama menetap di Kampung Merejemeg (di atas 20 tahun) sehingga menganggap hutan merupakan hak adat atas tanah yang masih ditumbuhi dengan pepohonan. Hak penguasaan hutan adat seringkali mengalami pelemahan ketika masyarakat mengambil hasil hutan kayu untuk dibawa keluar kampung dan kemudian disita oleh aparat pemerintah. Hal tersebut terjadi karena ada tumpang tindih antara klaim wilayah adat dengan klaim kawasan hutan negara. Hutan berdasarkan statusnya terdiri atas hutan negara dan hutan hak. Dalam UU No 41 tahun 1999 tentang Kehutanan, hutan adat masuk sebagai bagian dari hutan negara dan bukan sebagai hutan hak, sehingga negaralah yang mempunyai wewenang penuh untuk mengatur dan memutuskan persediaan, peruntukan, pemanfaatan, pengurusan, serta hubungan hukum yang terjadi di wilayah hutan negara. Akibatnya hutan adat sebagai bagian dari hak masyarakat menjadi terabaikan dan bahkan dilanggar hak-haknya oleh negara. Kondisi ini sejalan dengan apa yang disampaikan Kartodihardjo (2013), terdapat tumpang tindih areal hutan adat dengan berbagai fungsi kawasan hutan dan areal yang sudah diberi ijin oleh pemerintah kepada pihak lain. Mekanisme hak yang tidak memperhatikan kondisi lapangan, mengakibatkan sengketa antara pihak luar yang memiliki izin usaha dengan masyarakat sebagai pemilik lahan yang diperoleh dari mekanisme struktur (Napitu et al. 2017). Hak atas lahan yang terdapat pada masyarakat adat yang diatur secara turun-temurun, jika diabaikan dapat berpotensi konflik dan dapat mempercepat deforestasi (Zhang 2016; Pakniany et al. 2017).

Sistem penguasaan lahan hutan pada masyarakat adat selalu berbicara tentang hak-hak atas lahan hutan yang diperoleh berdasarkan aturan yang berlaku dalam masyarakat adat. Hak untuk menguasai kawasan hutan berawal dan bersumber dari kegiatan masyarakat membuka kawasan hutan yang belum tergarap untuk menjadi miliknya. Menurut Nugraha dan Murtijo (2013), perolehan hak milik yang bersifat tradisional ini relevan dengan kajian teori "occupatio" yakni pendudukan tanah-tanah yang dianggap belum dimiliki oleh seseorang. Hubungan manusia dengan sumber daya hutan sangat ditentukan oleh intensitas penggunaan atau penggarapan sumber daya hutan. Semakin intens penggarapan sumber daya hutan maka semakin kokoh penguasaannya.

\section{Persepsi Masyarakat tentang Kelestarian Hutan Adat}

Berdasarkan hasil wawancara diketahui bahwa persepsi masyarakat etnis Meyah tentang kelestarian hutan adat adalah kuat (skor 243). Walaupun sebagian besar (sekitar 70\%) masyarakat memiliki tingkat pendidikan yang rendah, namum kearifan lokal mendukung dalam menjaga alam menjadi bagian dari kehidupan etnis Meyah secara turun temurun. Nilai kearifan budaya lgya Ser Hanjob yang berarti "berdiri menjaga batas". Secara filosofis, nilai kearifan ini mengandung makna bahwa segala yang ada di alam ini (termasuk manusia) memiliki batas. Apabila batas yang ditetapkan dan disepakati dilanggar, maka diyakini akan berbuah bencana (Ataribaba et al. 2020). Kerusakan hutan yang terjadi saat ini disebabkan oleh pihak luar terutama dengan mulai dibukanya areal hutan untuk perkebunan kelapa sawit. Persepsi masyarakat terhadap kelestarian hutan adat seperti Tabel 7.

Tabel 7. Persepsi Masyarakat tentang Kelestarian Hutan Adat Table 7. Community Perceptions of Preservation of Customary Forests

\begin{tabular}{|c|c|c|c|c|c|c|c|}
\hline \multirow{2}{*}{$\begin{array}{c}\text { Jenis } \\
\text { Responden }\end{array}$} & \multirow{2}{*}{ BR } & \multirow{2}{*}{$\begin{array}{l}\text { Persespsi } \\
\text { Responden }\end{array}$} & \multirow{2}{*}{ SP } & \multicolumn{3}{|c|}{ Jumlah } & \multirow{2}{*}{ SAP } \\
\hline & & & & TM & $\mathbf{A P}$ & MA & \\
\hline TM & 3 & KUAT & 3 & 6 & 4 & 10 & 190 \\
\hline AP & 2 & NETRAL & 2 & 4 & 1 & 3 & 51 \\
\hline \multirow[t]{2}{*}{ MA } & 1 & LEMAH & 1 & 0 & 0 & 2 & 2 \\
\hline & & JUMLAH & & 10 & 5 & 15 & 243 \\
\hline
\end{tabular}


Keterangan: $\mathrm{TM}=$ Tokoh Masyarakat; $\mathrm{AP}=$ Aparat Pemerintah; $\mathrm{MA}=$ Masayarakat Adat $/$ Kampung

$\mathrm{BR}=$ Bobot Responden; SP $=$ Skor Penilain; SAP $=$ Skor Akhir Persepsi Klasifikasi Persepsi: 55 - 128 (Lemah); 129 - 202 (Netral); 203 - 276 (Kuat)

Masyarakat adat etnis Meyah yang sudah lama menetap di kampung Merejemeg (di atas 20 tahun) dengan tingkat pendidikan yang rendah memiliki pemahaman bahwa tidak semua lahan hutan harus dibuka secara luas dalam sekali musim tanam. Namun pola berladang (berkebun) yang dilakukan adalah dengan pola perladangan berpindah. Ladang berpindah (shifting cultivation) merupakan suatu bentuk sistem pertanian tradisional yang telah lama dipraktekkan di beberapa daerah. Ataribaba et al. (2020) mengatakan bahwa ladang berpindah merupakan pola pertanian tradisional yang diterapkan secara evolutif oleh masyarakat lokal dalam mewujudkan ketahanan pangan. Perladangan berpindah di Papua Barat juga ditemukan di pegunungan Arfak. Hujairin et al. (2012) menegaskan bahwa perladangan berpindah bagi masyarakat pedalaman suku Arfak merupakan cara bertani yang sudah lama ada sejak leluhur.

\section{Persepsi Masyarakat tentang Pemanfaatan Hutan Adat}

Masyarakat etnis Meyah mempunyai persepsi yang kuat atau postif (skor 245) tentang pemanfaatan hutan adat. Masyarakat etnis Meyah memahami dan mengetahui bahwa hutan adalah sumber kehidupan bagi mereka. Aktivitas pemanfaatan hutan untuk berkebun dan memungut hasil hutan kayu maupun yang bukan kayu adalah satu-satunya cara untuk memenuhi kebutuhan keluarga dan menambah pendapatan ekonomi keluarga atau marga yang menguasai lahan hutan. Kondisi yang sama dialami masyarakat Kasepuhan Pasir Eurih di Provinsi Banten yang menggantungkan kehidupannya pada sektor pertanian dan kehutanan (Pratiwi et al. 2019). Persepsi Masyarakat tentang pemanfaatan hutan adat oleh masyarakat etnis Meyah disajikan pada Tabel 8.

Tabel 8. Persepsi Masyarakat tentang Pemanfaatan Hutan adat

\begin{tabular}{cccccccc}
\hline \multirow{2}{*}{$\begin{array}{c}\text { Jenis } \\
\text { Responden }\end{array}$} & BR & $\begin{array}{c}\text { Persespsi } \\
\text { Responden }\end{array}$ & SP & \multicolumn{3}{c}{ Jumlah } & SAP \\
\cline { 6 - 7 } TM & 3 & KUAT & 3 & 9 & 2 & 11 & 210 \\
\hline AP & 2 & NETRAL & 2 & 1 & 3 & 2 & 33 \\
\hline MA & 1 & LEMAH & 1 & 0 & 0 & 2 & 2 \\
\hline & & JUMLAH & & $\mathbf{1 0}$ & $\mathbf{5}$ & $\mathbf{1 5}$ & $\mathbf{2 4 5}$ \\
\hline
\end{tabular}

Keterangan: $\mathrm{TM}=$ Tokoh Masyarakat; $\mathrm{AP}=$ Aparat Pemerintah; $\mathrm{MA}=$ Masayarakat Adat/Kampung $\mathrm{BR}=$ Bobot Responden; SP = Skor Penilain; SAP = Skor Akhir Persepsi Klasifikasi Persepsi: 55 - 128 (Lemah); 129 - 202 (Netral); 203 - 276 (Kuat)

Hampir sebagian besar matapencaharian masyarakat etnis Meyah adalah petani dengan tingkat pendidikan yang rendah. Namun aktivitas pemanfatan hutan ini sudah lama dilakukan secara turun temurun. Pola tanam perladangan berpindah dengan luas lahan 0,25 0,50 hektar untuk sekali musim tanam. Sebagian besar (70\%) masyarakat kampung Merejemeg memilik mata pencaharian sebagai petani. Untuk memenuhi kebutuahn hidupnya masyarakat memanfaatkan hutan adat sebagai lahan berkebun dengan. Kegiatan ini telah dilakukan sejak jaman nenek moyang sampai sekarang, dan masyarakat menganggap kegiatan berkebun ini tidak merusak hutan. Menurut masyarakat luasan yang dibuka hanya terbatas yaitu dengan luas sekitar 0,03-0,05 hektar dan dilakukan hanya untuk sekali musim tanam. Rotasi kebun lama ke kebun yang baru sekitar 5 tahun. 
Jurnal Belantara Vol. 4, No 2, Agustus 2021 (207-222)

\section{Faktor-Faktor Penentu yang Mempengaruhi Masyarakat Etnis Meyah Memanfaatkan Hutan Adat}

Masyarakat adat etnis Meyah di Kampung Merejemeg memanfaatkan lahan hutan, terutama untuk memenuhi kebutuhan hidupnya. Terdapat beberapa faktor penentu yang mempengaruhi masyarakat etnis Meyah memanfaatkan hutan adat, yang terdiri dari: a) faktor dasar, b) faktor pendukung, dan c) faktor pendorong. Faktor dasar yang menjadi penentu dalam mempengaruhi masyarakat memanfaatkan hutan adalah adat istiadat dan pandangan hidupnya tentang hutan adat. Masyarakat etnis suku Meyah memiliki tradisi bahwa hutan merupakan sumber kehidupan yang diberikan oleh Tuhan sang pencipta kepada mereka. Hutan menjadi tempat interkasi sosial dan inspirasi dalam membangun hubungan dengan alam dan sang pencipta. Aspek lama bermukim dan jenis matapencaharian (pekerjaan) masyarakat etnis Meyah merupakan faktor pendukung dalam memanfaatkan hutan adat. Kondisi ini seperti yang dilaporkan Syviani (2008) tentang masyarakat asli Suku Anak Dalam (SAD) yang telah mendiami Taman Nasional Bukit Dua Belas (TNBD) selama puluhan tahun. SAD menyebut hutan yang ada di TNBD sebagai daerah pengembaraan; dimana mereka berinteraksi dengan alam, saling memberi, saling memelihara dan saling menghidupi. Mereka menggantungkan hidup sepenuhnya baik ekonomi, sosial dan budaya dari kawasan hutan yang ada disekitarnya. Hutan bukan hanya merupakan sumber penghidupan berladang, berburu dan memanen hasil hutan tetapi juga berkaitan erat dengan budaya tradisi. Sedangkan peranan tokoh adat dan tokoh agama merupakan faktor pendorong bagi masyarakat etnis Meyah dalam memanfaatkan hutan adat (Suhartini 2009).

\section{KESIMPULAN DAN SARAN}

Konsep hutan adat menurut masyarakat etnis Meyakh adalah areal hutan yang diberikan oleh Tuhan Pencipta Alam Semesta sebagai hak milik manusia untuk hidup secara turun-temurun, berkembang biak dan beradaptasi dengan lingkungannya, serta memanfaatkan sumberdaya alam yang ada di dalam hutan. Berdasarkan aturan dan norma yang berlaku dalam masyarakat adat, sistem penguasaan lahan hutan oleh masyarakat etnis Meyakh terbagi terbagi atas 3 bentuk yaitu: 1) penguasaan lahan hutan sebagai satu kesatuan wilayah adat dengan kampung, 2) penguasaan lahan hutan oleh kelompok marga dan 3) penguasaan lahan hutan oleh individu (keluarga).

Masyarakat etnis Meyah memiliki persepsi yang kuat tentang kepemilikan hutan adat. Masyarakat memahami bahwa hutan yang berada di sekitar kampung merupakan hutan adat yang menjadi miliknya. Persepsi masyarakat etnis Meyah tentang kelestarian hutan adat adalah kuat. Hal ini mengingat adanya nilai kearifan lokal lgya Ser Hanjob dalam menjaga alam menjadi bagian dari kehidupan etnis Meyah secara turun temurun. Persepsi masyarakat etnis Meyah tentang pemanfaatan hutan adat adalah kuat. Hal ini disebabkan masyarakat etnis Meyah memahami bahwa hutan adalah sumber kehidupan.

Faktor-faktor yang mempengaruhi masyarakat etnis Meyah dalam pemafaatan hutan adat terdiri atas a) faktor dasar yaitu: adat istiadat dan pandangan hidup tentang hutan; b) faktor pendukung yaitu: matapencaharian dan lama bermukim, serta c) faktor pendorong yaitu: peran dari tokoh adat dan tokoh agama. 


\section{DAFTAR PUSTAKA}

Agrawal, A. 2003. Sustainable Governance of Commonpool Resources: Context, Methods, and Politics. Annu. Rev. Anthropol. 32: 243-262.

Andrasmoro, D., dan E. E. Nurekawati. 2017. Analisis Pengembangan Kebijakan Hutan Tanaman Rakyat (HTR) Terhadap Peningkatan Kesejahteraan Masyarakat Di Kalimantan Barat dan D.I Yogyakarta. Jurnal Swarnabhumi Vol. 2, No. 1, Februari 2017

Ataribaba, Y., I. Setiawan, T.I. Noor. 2020. Pola Pergeseran Nilai Kearifan Lokal Sistem Ladang Berpindah Pada Masyarakat Arfak. Mimbar Agribisnis. Jurnal Pemikiran Masyarakat Ilmiah Berwawasan Agribisnis. Juli 2020. 6(2): 812-832

Badola, R., S. Barthwal, dan S.A. Hussain. 2012. Attitudes of local communities towards conservation of mangrove forests: A case study from the east coast of India. Estuarine, Coastal and Shelf Science 96: 188-196.

Budiandrian, B., Adiwibowo S., dan Kinseng RA. 2017. Dinamika Tenurial Lahan Pada Kawasan Hutan Konservasi (Studi Kasus Di Taman Hutan Raya Sultan Thaha Saifuddin). Sodality 5(3): 210-217. DOI: 10.22500/sodality.v5i3.19394

Chowdhury, M.S.H., C. Gudmundsson, S. Izumiyama, M. koike, N. Nazia, M.D.P. Rana., S.A. Mukul, N. Muhammed, dan M. Redowan. 2014. Community attitudes toward forest conservation programs through collaborative protected area management in Bangladesh. Environmnet Dev Sustain 16(6): 1-18.

Dewi, B.S., A. Kamaluddin, dan Y. Gdemakarti. 2019. Persepsi Masyarakat terhadap Pengembangan Penangkaran Rusa (Cervus sp.) di Kota Bandar Lampung. Jurnal Sylva Lestari Vol. 7 No. 2, Mei 2019 (244-254)

Erwiantono. 2006. Kajian Tingkat Partisipasi Masyarakat dalam Pengelolaan Ekosistem Mangrove di Kawasan Teluk Pangpang-Banyuwangi (The community participation in mangrove ecosystem management in Pangpang Bay, Muncar-Banyuwangi). EPP 3: 4450.

Fajrini, R. 2015. Hak Biokultural Masyarakat Dalam Kebijakan Konservasi Sumber Daya Hayati. Jurnal Hukum Lingkungan Vol. 2 Issue 2, Desember 2015

Farouque, M.G., K. Fuyuki dan N. Takashino. 2017. Attitudes of local people towards community-based forest management: A study of a Sal forest area in Bangladesh. International Journal of Agricultural Extension and Rural Development. Vol. 4 (1), pp. 263273

Febryano, IG., D. Suharjito, D. Darusman, C. Kusmana, dan A. Hidayat. 2015. Aktor Dan Relasi Kekuasaan Dalam Pengelolaan Mangrove Di Kabupaten Pesawaran, Provinsi Lampung, Indonesia (Actors and Power Relation in Mangrove Management in Pesawaran Regency, Lampung Province, Indonesia). Jurnal Analisis Kebijakan Kehutanan Vol. 12 No. 2, Agustus 2015: 123-138 
Hujairin M., A. Ismadi, T. Kustana. 2017. Revitalisasi Kearifan Lokal Suku Arfak di Papua Barat dalam Rangka Mendukung Ketahanan Pangan Wilayah. Jurnal Prodi Manajemen Pertahanan, 3(1), 53-77.

Infield, M. and A. Namara. 2001. Community attitudes and behaviour towards conservation: an assessment of a community conservation programme around Lake Mburo National Park, Uganda. Oryx 35(1): 48-60.

Kartodiharjo, H. 2013. Kajian Putusan MK. 35/PUU-X/2012. Kelola Hutan Baru Dengan Mindset Dan Kepentingan Politik Lama. Warta Tenure Edisi 11.

KEMENDAGRI. 2014. Peraturan Menteri Dalam Negeri Nomor 52 Tahun 2014 Tentang Pedoman Pengakuan dan Perlindungan Masyarakat Hukum Adat. Kemenrtian Dalam Negeri. Jakarta

KLHK. 2018. Status Hutan dan Kehutanan 2018. Kementrian Lingkungan Hidup dan Kehutanan, Jakarta.

Kothari, A., S. Suri, S. dan N. Singh. 1995. People and protected areas: Rethinking conservation in India. The Ecologist 25(5): 188-194.

Kristin, Y., R. Qurniati, dan H. Kaskoyo. 2018. Interaksi Masyarakat Sekitar Hutan Terhadap Pemanfaatan Lahan Taman Hutan Raya Wan Abdul Rachman. Jurnal Sylva Lestari, 6 (3): 1-8.

Magdalena. 2013. Peran Hukum Adat dalam Pengelolaan dan Perlindungan Hutan Di Desa Sesaot, Nusa Tenggara Barat dan Desa Setulang, Kalimantan Timur. Jurnal Penelitian Sosial dan Ekonomi Kehutanan Vol. 10 No. 2 Juni 2013.

Masripitin, N. 2007. Peran Hutan Tropika Terhadap Peningkatan Pelestarian Hutan Global. Makalah dalam Seminar Klaster Riset Universitas Gadjah Mada, 30 Oktober 2007. Yogyakarta.

Muspida. 2008. Kearifan Lokal Dalam Pengelolaan Hutan Kemiri Rakyat Di Kabupaten Maros Sulawesi Selatan. Jurnal Hutan Dan Masyarakat Vol. III No. 2 Agustus 2008, $111-234$

Napitu, JP, A. Hidayat, S. Basuni B, dan S. Syaf. 2017. Mekanisme Akses Pada Hak Kepemilikan Kesatuan Pegelolaan Hutan Produksi Meranti, Sumatera Selatan. Jurnal Penelitian Sosial dan Ekonomi 14(2): 101-118. DOI: 10.20886/jpsek.2017.14.2.101118

Negara, P.D. 2011. Rekonstruksi Kebijakan Pengelolaan Kawasan Konservasi Berbasis Kearifan Lokal Sebagai Kontribusi Menuju Pengelolaan Sumber Daya Alam Yang Indonesia. Jurnal Konstitusi, Vol. IV, No. 2, November 2011

Nugraha, A dan Murtijo. 2005. Antropologi Kehutanan. Cetakan 1. Penerbit Wana Aksara. Banten. 
Pakniany, Y., E. Soetarto dan S. Adiwibowo. 2017. Pertambangan Emas di Wilayah Maluku Barat Daya: Kutukan atau Berkah? (Studi Kasus Konflik Akses Sumber Agraria). Sodality 5(2): 163-170.

Pratiwi, R. Tb. U. Nitibaskara dan M.L Salampessy. 2019. Kelembagaan Masyarakat Dalam Pengelolaan Hutan Adat (Studi Kasus di Kasepuhan Pasir Eurih, Desa Sindanglaya, Kecamatan Sobang, Kabupaten Lebak, Provinsi Banten). Jurnal Belantara Vol. 2, No. 1, Maret 2019 (62-69) DOI: https://doi.org/10.29303/jbl.v2i1.131

Putri, S.H., H. Prayogo, R.S. Wulandari. 2019. Inventarisasi Jenis-Jenis Lumut Di Kawasan Hutan Adat Bukit Benuah Kabupaten Kubu Raya. Jurnal Hutan Lestari (2019) Vol. 7 (3) :1035 - 1047

Putri, N. A., B. Masy'ud, dan H. Gunawan. 2019. Persepsi Masyarakat Terhadap Taman Rusa Bumi Patra Indramayu, Jawa Barat. Jurnal Penelitian Hutan dan Konservasi Alam (2019), 16(1): 13-24

Rahlem, D., D. Yoza, dan T. Arlita. 2017. Persepsi Pengunjung dan Partisipasi Masyarakat dalam Pengelolaan Ekowisata Air Terjun Aek Martua Di Kabupaten Rokan Hulu. JOM Faperta.4(1).

Ratsimbazafy, C.L., K. Harada, K. dan M. Yamamura. 2012. Forest Resource Use, Attitude, and Perception of Local Residents Towards Community Based Forest Management: Case of the Makira Reducing Emissions from Deforestation and Forest Degradation (REDD) Project, Madagascar. Journal of Ecology and the Natural Environment 4(13): 321-332.

Riduwan. 2008. Skala Pengukuran Variabel-Variabel Penelitian. Penerbit Alfabeta. Bandung.

Ritohardoyo, S., dan Ardi. 2011. Arahan Kebijakan Pengelolaan Hutan Mangrove: Kasus Pesisir Kecamatan Teluk Pakedai Kabupaten Kubu Raya Provinsi Kalimantan Barat. Jurnal Geografi, 8: 83-94.

Ronsumbre, A. 2020. Ensiklopedia Suku Bangsa Di Provinsi Papua Barat. Penerbit Kepel Press. Yogyakarta

Ruhimat, I.S. 2010. Implementasi Kebijakan Kesatuan Pengelolaan Hutan (KPH) Di Kabupaten Banjar. Jurnal Analisis Kebijakan Kehutanan. Vol. 7 No. 3, Desember 2010: 169 - 178

Rusdianti, K dan S. Sunito. 2012. Konversi Lahan Hutan Mangrove Serta Upaya Penduduk Lokal Dalam Merehabilitasi Ekosistem Mangrove (Mangrove Forest Conservation and The Role of Local Community in Mangrove Ecosytems Rehabilitations). Jurnal Sosiologi Pedesaan Vol. 06, No. 01, April 2012, hlm. 1-17

Sahlan. 2012. Kearifan Lokal Masyarakat Tau Taa Wana Bulang dalam Mengkonservasi Hutan di Propinsi Sulawesi Tengah. Jurnal Mimbar Hukum Vol. 24 No 2.

Situmorang, R.O.P dan E.R. Simanjuntak. 2015. Kearifan Lokal Pengelolaan Hutan oleh Masyarakat Sekitar Kawasan Taman Wisata Alam Sicike-cike, Sumatra Utara. Widyariset, Volume 18, Nomor 1, April 2015. Hal 145-154 
Siu, M.G.L, S. Amanah, dan N. Santoso. 2020. Partisipasi Masyarakat Lokal dalam Pengelolaan Ekowisata Mangrove di Kelurahan Oesapa Barat Kota Kupang. Jurnal Tengkawang Vol. 10 (1): $62-74$

Suhartini. 2009. Kajian Kearifan Lokal Masyarakat dalam Pengelolaan Sumberdaya Alam dan Lingkungan. Prosiding Seminar Nasional Penelitian, Pendidikan dan Penerapan MIPA, Fakultas MIPA, Universitas Negeri Yogyakarta, 16 Mei 2009

Susanto, D., L.R.W. Faida, F.R.H. Lubis, dan R. Hanisaputra. 2020. Interaksi Masyarakat Sekitar dengan Kawasan Cagar Alam dan Cagar Alam Laut pangandaran. Jurnal Belantara Vol. 3, No. 2, Agustus 2020 (97-104) DOl: https://doi.org/10.29303/jbl.v3i2.474

Sugiyono. 2011. metode Penelitian Pendidikan: Pendekatan Kuantitatif, Kualitatif, dan R\&D. Penerbit Alfabeta. Bandung.

Syahputra, OK.H., B. Nugroho, H. Kartodihardjo, dan N. Santoso. 2021. Kelembagaan Pengelolaan Mangrove Berbasis Masyarakat Di Kesatuan Pengelolaan Hutan Model Wilayah lii Provinsi Aceh, Indonesia. Jurnal Belantara Vol. 4, No. 1, Maret 2021 (11-25) DOI: https://doi.org/10.29303/jbl.v4i1.594

Sylviani. 2008. Kajian Dampak Perubahan Fungsi Kawasan Hutan Terhadap Masyarakat Sekitar. Jurnal Penelitian Sosial dan Ekonomi Kehutanan Vol. 5 No. 3 September 2008

Tadesse, S. A., dan D. Teketay. 2017. Perceptions and attitudes of local people towards participatory forest management in Tarmaber District of North Shewa administrative zone, Ethiopia: the case of Wof-washa Forests. Journal of Ecoogical Process, 6(17): 1-16.

Wells, M.P dan K.E. Brandon. 1993. The principles and practice of buffer zones and local participation in biodiversity conservation. Ambio 22(2-3): 157-162.

Zhang, D. 2016. Payments for Forest-Based Environmental Services: A Close Look. Forest Policy and Economics (72): 78-84. DOI: 10.1016/j.forpol.2016.06.017. 